\title{
Systematic Comparative Illustration of Primary School Building Regulations in Serbia and Slovenia
}

\author{
Sanja Stevanovic, PhD \\ Mathematical Institute, Serbian Academy of Sciences and Arts, \\ Belgrade, Serbia
}

doi: 10.19044/esj.2017.v13n22p267 URL:http://dx.doi.org/10.19044/esj.2017.v13n22p267

\begin{abstract}
PISA tests provide international comparison of achieved educational standards through testing capabilities of 15-year old pupils. Serbia participates in PISA tests since 2003 and test reports show that the results of Serbian pupils are statistically significantly below the average of pupils in OECD countries. An additional concern, however, is the fact that the results of Serbian pupils are also statistically significantly below the results of Slovenian pupils. Slovenia participates in PISA tests since 2006 and the results of its pupils do not differ significantly from the OECD average. In order to discover directions for future reforms of educational system in Serbia in order to reach the OECD average, and therefore Slovenia, it is necessary to compare individual factors of educational systems in Serbia and Slovenia. Since pedagogical vision is of fundamental importance in design of schools, differences in primary school design regulations may serve to illustrate the most important differences in educational systems as well. A systematic comparative illustration of primary school design regulations in Serbia and Slovenia in this paper reveal that schools in Slovenia dedicate much more space, both quantitatively and qualitatively, to youngest pupils in preschool and the first two grades, school library and gym than their counterparts in Serbia.
\end{abstract}

Keywords: Primary school design, early grade classrooms, school library, gym.

\section{Introduction}

PISA (abbreviated from Programme for International Student Assessment) assessments provide international comparison of educational standards through testing capabilities of 15-year old pupils. Pupils are tested in three areas: comprehension of written text, mathematics and natural sciences. The assessment program has been developed by OECD countries 
and assessments are performed every three years since 2000. Serbia has participated in four PISA assessments since 2003, but ceased to participate in the 2015 assessment. Earlier assessment reports (OECD, 2004; OECD, 2007; OECD, 2010; OECD, 2014) showed that the results of Serbian pupils are statistically significantly below the average of pupils in OECD countries. An additional concern is the fact that the results of Serbian pupils are also statistically significantly below the results of Slovenian pupils. Slovenia participates in PISA assessments since 2006, and results of its pupils in these assessments do not differ significantly from the average of pupils in OECD countries. Diagrams in Figure 1 show the results of Serbian and Slovenian pupils in different assessment areas, compared to average results of OECD countries in the 2006, 2009 and 2012 assessments in which both countries participated. Detailed assessment results are available in the abovementioned reports and at the PISA web site http://www.oecd.org/pisa.
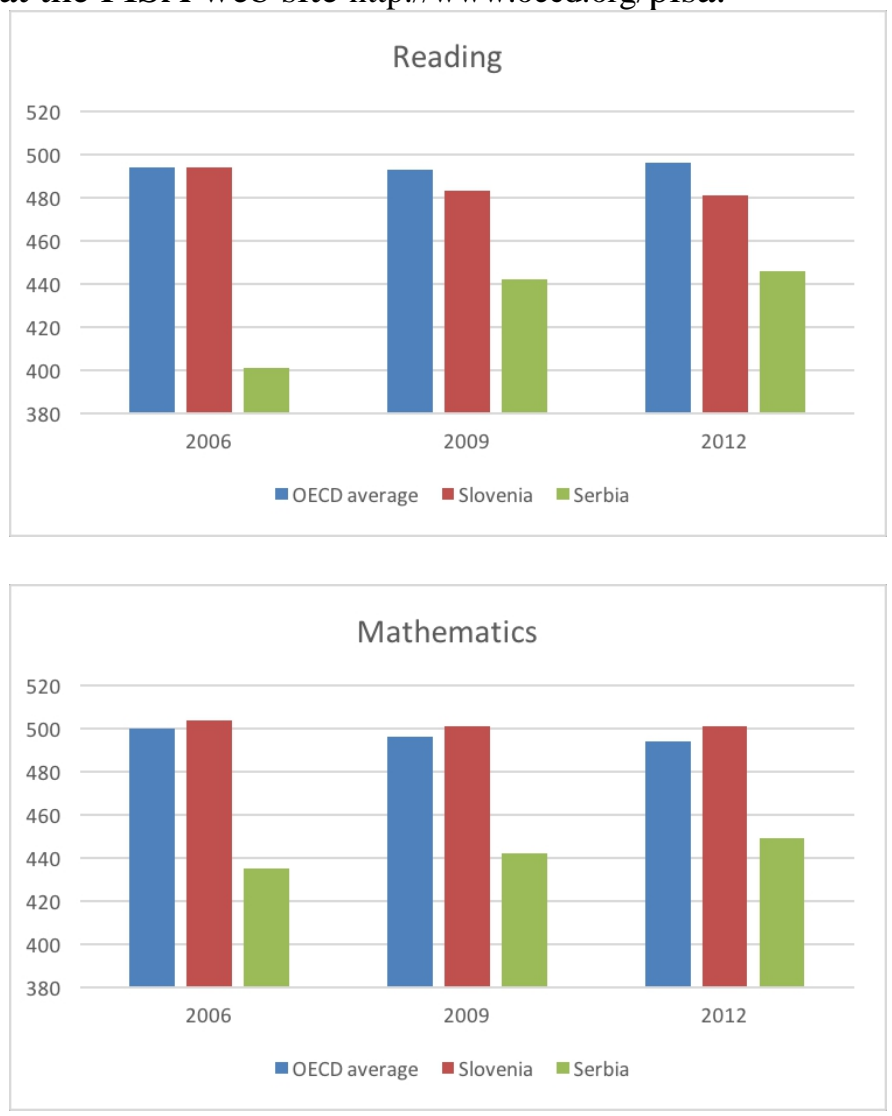


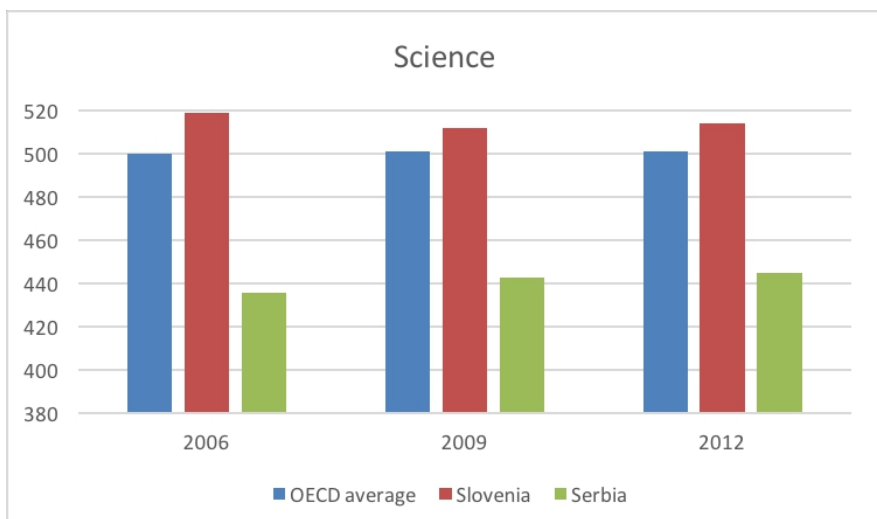

Figure 1. Performance of pupils in Slovenia and Serbia in the 2006, 2009 and 2012 PISA assessments compared to the OECD average (OECD, 2007; OECD, 2010; OECD, 2014).

Having in mind that Serbia and Slovenia belonged to the same country for most of the XX century, from 1918 to 1991, and had the same educational system, it is natural to expect that the results of their pupils until 1991 would be statistically similar. Reasons for a significant decline in achievement levels of Serbian pupils compared to Slovenian ones in the last two decades might be sought in general degradation of economic situation in Serbia during the 1990s, enormous levels of emigration and slow, if not almost stagnant, recovery of society and economics since the beginning of the XXI century. This decline is certainly a consequence of complex interaction of different factors: economical, societal, political, cultural, educational etc. However, before one can go on to study implications of interactions of different factors, one first has to fully understand differences of individual factors in Serbia and Slovenia by performing their comparative analyses, in order to identify those that can significantly influence pupils' performance. Two more such studies appeared recently. Kadijević, Žakelj and Gutvajn (2015) compared the aspects of mathematics curricula, teaching practices and teachers' professional development and studied their influence on differences in mathematics achievements of fourth graders in Slovenia and Serbia. On the other hand, Popović, Cvetković and Krašna (2015) compared the presence and use of information and communication technologies in education in Slovenia and Serbia.

The topic of this manuscript are differences in design regulations of primary schools in Slovenia and Serbia. According to Wiegelmann (2003), "Pedagogical vision is of fundamental importance in design of schools", so that differences in primary school design regulations may serve to illustrate important differences in educational systems as well. Architecture has, in an appropriate amount, a direct influence on the learning process: well designed space can help and support learning, while badly designed space can impede 
it. This is in line with Perkins (2001) that "the task of architecture is to create school environment that will be stimulating, surprising and comfortable." The influence of school design on various aspects of academic achievement have been studied by a number of researchers before. Tanner (2000) found that four design factors to correlate with student learning outcomes in elementary schools in USA: access to technology for teachers, freedom of movement within the school and among learning environments, overall positive impression of the learning environment and positive outdoor spaces that are in harmony with nature. Barrett, Zhang, Moffat and Kobbacy (2013) showed that six design parameters of the built environment: colour, choice, connection, complexity, flexibility and light have demonstrable impact on the learning rates of pupils in primary schools. In a study of college algebra freshman classes in USA, Safer, Farmer, Segalla and Elhoubi (2005) showed that the classroom aspect ratio matters and that "the closer students are to the teacher, the higher they will rate the teacher's effectiveness," concluding that classrooms should be wider than they are wide and confirming Niemeyer's (2003) note that "many [classroom] designers feel that a proportion of 1 unit deep by 1.3 units wide is the ideal length by width ratio" (p. 130). Lei (2010) provided a further review of literature on influences of physical design of classrooms on student learning and evaluations of college instructors in USA. Armitage (2005) explored links between school building design and children's use of outdoor environment for play, showing that designers often under-use potential of the informal use of school grounds and even concluding that "throughout history we see a picture of playground provision that is more accidental than integral to design."

Results of the systematic comparative illustration of current regulations for primary school design in Serbia and Slovenia are given in the following sections. Ordinance on standards of school space, equipment and teaching aids for primary schools (Ordinance on standards, 1990) from 1990 is still valid in Serbia. Slovenia made a revision of its regulations in 1999 (Plestenjak, Urbanc, Kovač, Leskovec \& Strel, 1999) in order to unify them with the legislative of the European Union. Already a cursory glance reveals common roots of these regulations. Their comparative analysis will show that schools in Slovenia dedicate much more space, both quantitatively and qualitatively, to youngest pupils in preschool and the first two grades, school library and gym than their counterparts in Serbia.

\section{Age division}

The first important difference between Slovenian and Serbian regulations is concerned with pupils' age division. Primary schools in Slovenia last for 9 years, where Slovenian grade 1 corresponds to preschool in Serbia, while Slovenian grades 2-9 correspond to Serbian grades 1-8. 
Instead of dividing pupils into lower and higher grades, Slovenian regulations divide pupils into three age groups:

- the first group is formed by Slovenian grades 1-3,

- the second group is formed by grades 4-6, while

- the third group is formed by grades 7-9.

This age division in Slovenia corresponds to the Bloom's division in his Taxonomy of Educational Objectives (Bloom, 1956) to the periods of middle childhood from 6-8 years, late childhood from 9-11 years and early adolescence from 12-14 years.

Due to differences in physical, emotional and mental development of children, pupils in grades 1-3 are functionally separate from older pupils and even have a separate entrance to their school space. This has an impact on the functional scheme for primary school design in Slovenia, shown in Fig. 2.

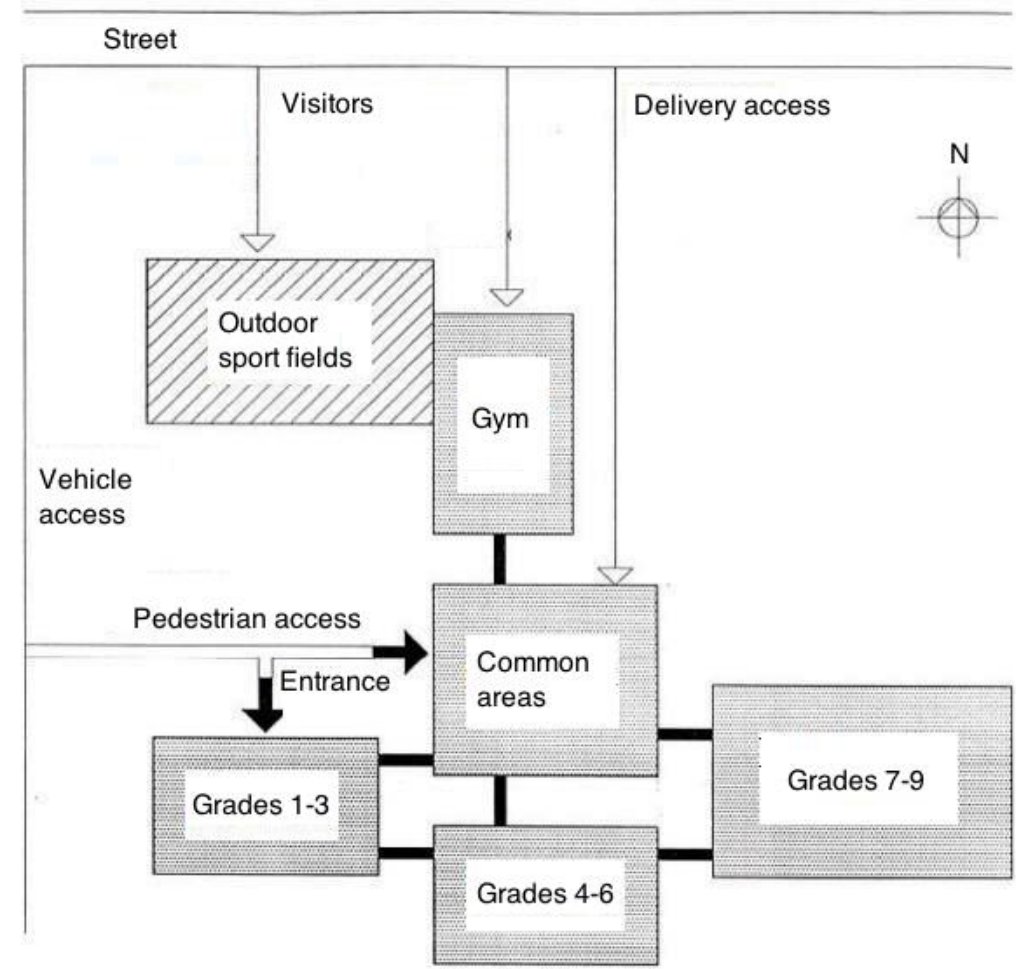

Figure 2. Functional scheme of primary school in Slovenian regulations (Plestenjak, Urbanc, Kovač, Leskovec \& Strel, 1999).

On the other hand, pupils in Serbia are still divided in just two age groups: younger grades 1-4 and older grades 5-8. Serbian regulations do envisage functional separation of younger grades from older grades, but do not provide for a separate entrance for younger grades. They further do not contain suggestions for the school functional scheme, although their 
examples are readily found in textbooks used at architectural faculties in Serbia.

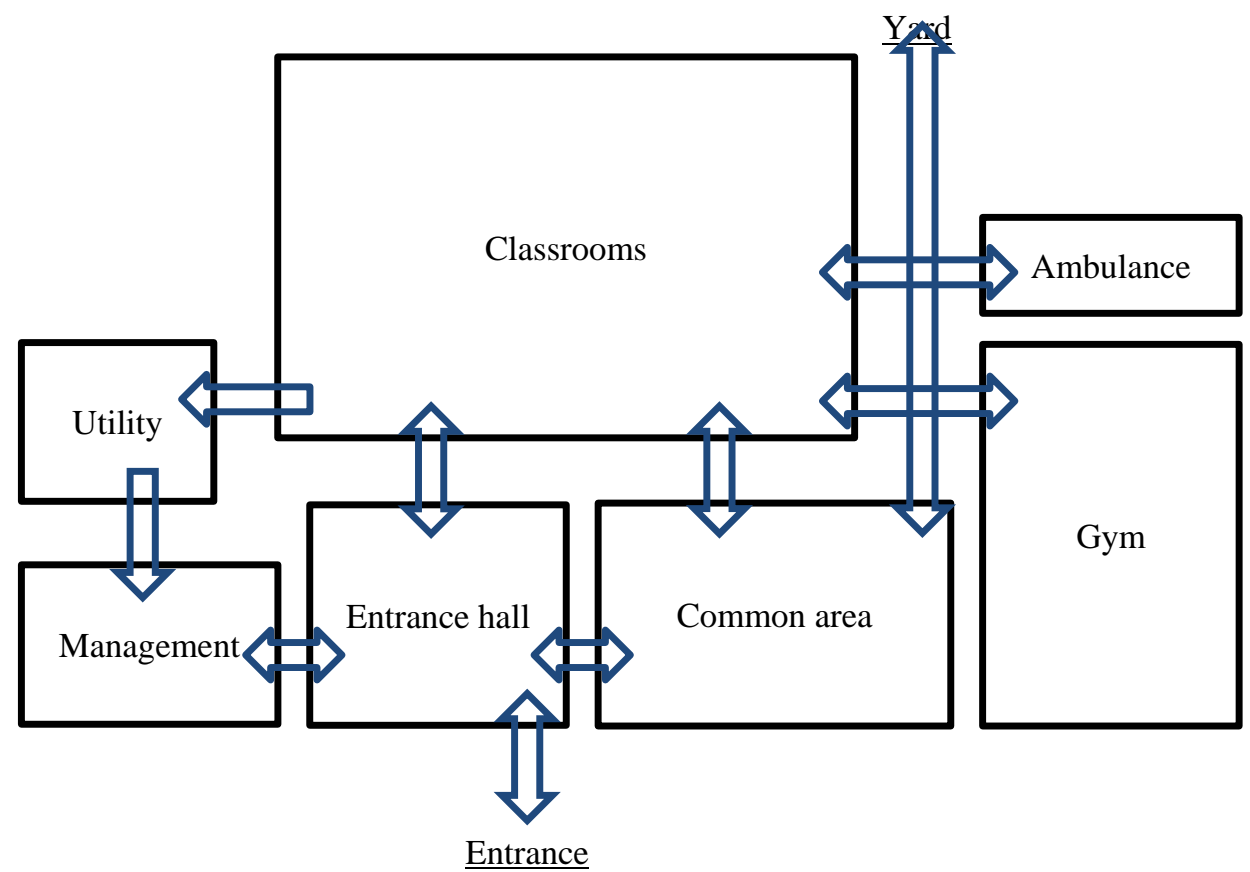

Figure 3. Functional scheme of primary school from an architectural textbook in Serbian (Anđelković, 1995).

\section{School opening hours}

Another large difference in regulations is concerned with opening hours: schools in Slovenia work in one shift only, while virtually all schools in Serbia work in two shifts. This difference, in addition to being beneficial for time management of parents in Slovenia, has great consequences for spatial organization, as it requires schools in Slovenia to be almost double in size for the same number of pupils when compared to those in Serbia.

Further important design implication, emphasized by Slovenian regulations, is that school space needs to be designed for multipurpose use in afternoons and evenings, after teaching period ends, and over weekends. Planned purposes encompass cultural and sport events, adult education, lectures, seminars, recreation etc. According to Behnisch and Sabatke (2003), "School building needs to be open and multivalent by its nature in order to provide space for a multitude of school activities, as well as for local societies and groups."

Contrary to Slovenia, teaching period in Serbian schools is, especially in urban environments, organized in two shifts, which results in 
daylong use of school space. Societal use of school space is therefore rare, except for gyms which are rented for recreational use in evenings and over weekends. Apart from rare exceptions, schools in Serbia are closed for public and have very specific use patterns (Anđelković, 1995).

\section{Classrooms for grades 1-3}

According to Slovenian regulations, classrooms for grades 1-3 form a separate entity, with its own entrance and central wardrobe, with the option to bypass the wardrobe when entering the school. Classrooms are $60 \mathrm{~m}^{2}$ in size, with teachers' office $20 \mathrm{~m}^{2}$ in size, situated in such a way that each classroom has an exit onto a partially covered, tiled yard. Additional $20 \mathrm{~m}^{2}$ of common area is envisaged for each first grade classroom, designed as an extension of space in front of the classroom which may also be used for teaching. Classrooms extended in this way offer the possibility of simultaneous teaching of multiple groups, recess between classes (playing area) and gradual switch to longer focused work.

Space for grades 1-3 also contains a small classroom for individual work and storage of teaching equipment and sanitary space of adequate size. Figures 4-6 show suggestions for spatial organization of classrooms for schools with 1, 2 and 3 classes per grade from the regulations document (Plestenjak, Urbanc, Kovač, Leskovec \& Strel, 1999).

Serbian regulations do not prescribe contents of the space for younger grades, but only vaguely mention transformation of pupils from objects into subjects of education (Ordinance on standards, 1990, p. 5). Suggestions for designing such space, such as the one shown in Figure 7, may again be found in architectural textbooks in Serbian. Still, the fact that this space is not mentioned in necessary detail may still result in simply separating a wing with several ordinary classrooms and proclaiming it a space for the youngest pupils, as is already done in a number of primary schools in Serbia.
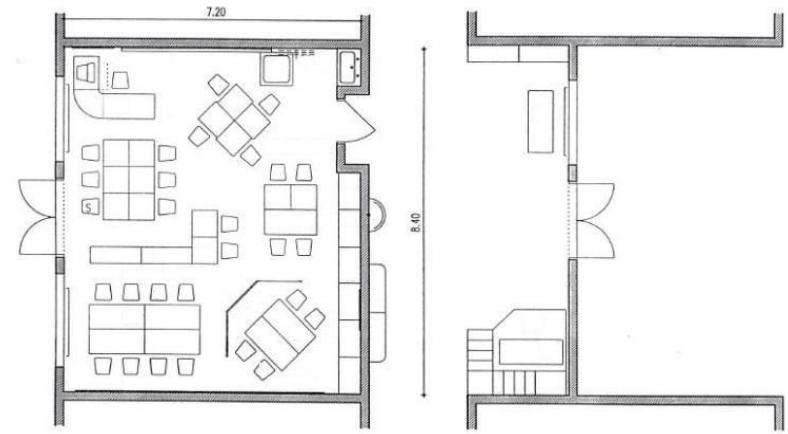

Figure 4. A $60 \mathrm{~m}^{2}$ classroom with $20 \mathrm{~m}^{2}$ of common area for one class (Plestenjak, Urbanc, Kovač, Leskovec \& Strel, 1999). 

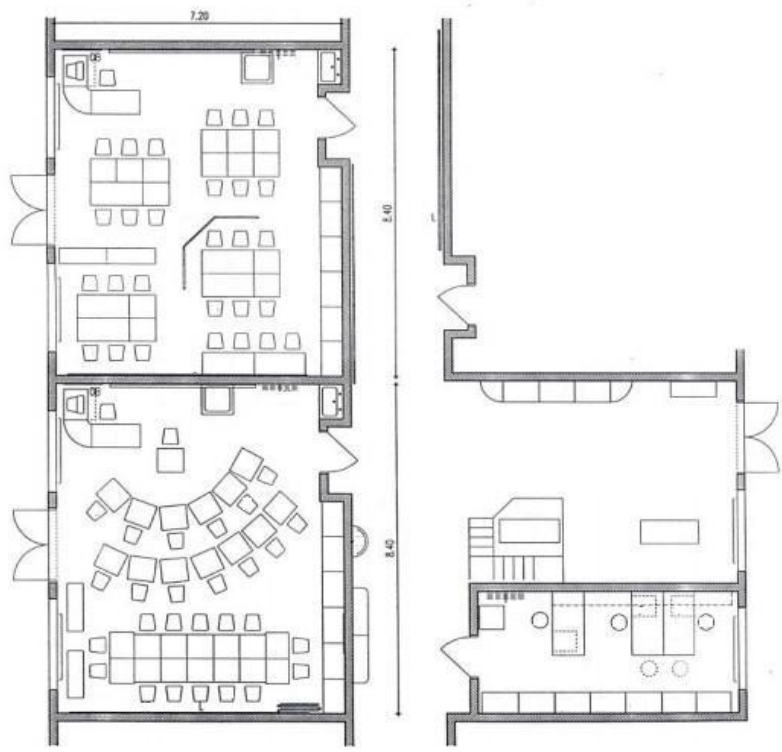

Figure $5.60 \mathrm{~m}^{2}$ classrooms with $40 \mathrm{~m}^{2}$ of common area for two classes and $20 \mathrm{~m}^{2}$ of teachers' office (Plestenjak, Urbanc, Kovač, Leskovec \& Strel, 1999).

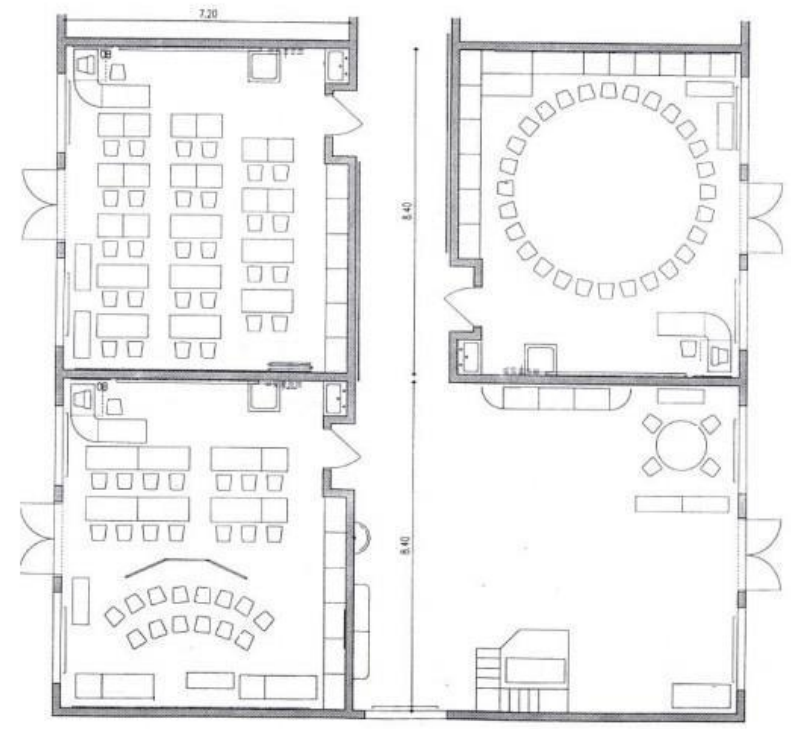

Figure 6. $60 \mathrm{~m}^{2}$ classrooms with $60 \mathrm{~m}^{2}$ of common area for three classes (Plestenjak, Urbanc, Kovač, Leskovec \& Strel, 1999). 


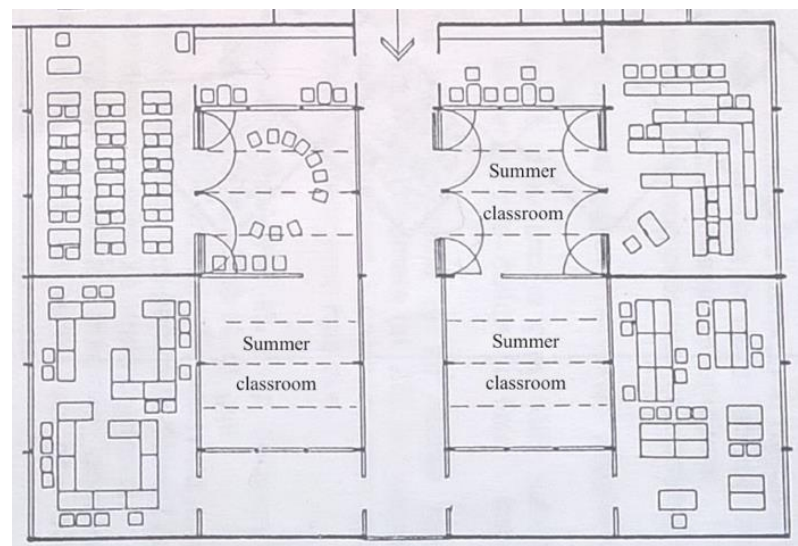

Figure 7. Open summer classrooms in atriums in front of ordinary classrooms for younger grades (Anđelković, 1995).

Serbian regulations, however, do prescribe that classrooms have $54 \mathrm{~m} 2$ in size. When this $10 \%$ decrease in size is compared to the fact that the average class in Serbia has 22 pupils (Kovačević, 2016), while that in Slovenia has 20 pupils (Marc \& Svetin, 2016), it turns out that the pupils' density in classrooms is $21 \%$ higher in Serbia than in Slovenia. This may have certain negative consequences in light of Rivlin and Wolf's (1972) claim that "aggression and destructive behavior increase as the number of children in a room increase", and Wohlwill and van Vliet's (1985) findings that "high density conditions have for consequence excess levels of stimulation, stress and arousal, reductions in desired privacy levels and loss of control." An additional concern is that higher classroom density in Serbia leads to higher $\mathrm{CO}_{2}$ levels which in turn degrade health, comfort and performance of pupils in Serbia.

\section{School library}

School library represents yet another differential aspect of Slovenian and Serbian regulations, first in the envisaged size and then in its contents. According to the Serbian regulations, school library should have $0.1-0.2 \mathrm{~m}^{2}$ per pupil $\left(160 \mathrm{~m}^{2}\right.$ in larger, central school with 800 pupils), while it should contain:

- book library with $36 \mathrm{~m} 2$ in size

- print and audio copying room with $18 \mathrm{~m}^{2}$ in size

- storage space for audio-visual equipment and teacher preparation with $36 \mathrm{~m}^{2}$ in size, and

- reading room with $72 \mathrm{~m}^{2}$ in size.

As regulations do not give further details, large percentage of designed school libraries is influenced by existing designs. High extent of such 
influences often limits the introduction of new concepts and ideas in design (Anđelković, 1995).

On the other hand, Slovenian regulations require more contemporary and better organized contents of school library. First, its size should vary from $0.34 \mathrm{~m}^{2}$ per pupil in largest schools up to $0.9 \mathrm{~m}^{2}$ per pupil in smallest schools. It should be placed in the central part of school building, in immediate vicinity of classrooms. Its necessary part is also a multimedia classroom, aimed for all computer-related teaching activities and work with contemporary electronic media. A suggestion for design solution from Slovenian regulations is shown in Fig. 6. Internal organization of library should enable different activities to proceed simultaneously: lectures, exhibitions, browsing of electronic media, renting of library materials etc.

\section{Gym and sport fields}

Slovenian regulations emphasize closed areas for sport activities in schools, while Serbian regulations put accent on open areas. Serbian regulations require all complete schools to have $9,250 \mathrm{~m}^{2}$ of open sport fields, while Slovenian regulations substantially lower the area for open sport fields, so that their area should be at least $1,300 \mathrm{~m}^{2}$ in schools with 9 classrooms, $2,100 \mathrm{~m}^{2}$ in schools with 18 classrooms and $2,815 \mathrm{~m}^{2}$ in schools with 27 classrooms.

On the other hand, Slovenian regulations require substantially larger area of gyms. According to Serbian regulations, all complete schools have a gym with one field of size $24 \mathrm{~m} \times 12 \mathrm{~m}$ in schools with up to 16 classrooms or $26 \mathrm{~m} \times 15 \mathrm{~m}$ in schools with more than 16 classrooms. In Slovenian regulations, gym size depends on school size and may contain several separate fields. A field may be used by at most 28 pupils (whole class) of grades $1-5$ at a time, or by at most 20 pupils of grades 6-9. Taking into account that each class has three classes of physical education per week and that the gym is used for 30 school hours during a week, one gets that a school with 9 classrooms has one field, a school with 18 classrooms has two fields, while a school with 27 classrooms has three fields in a gym. The first field always has the size of $24 \mathrm{~m} \times 15 \mathrm{~m}$, while the remaining fields may be either the same or one of the following:

- dancing-wrestling area of size $196 \mathrm{~m}^{2}$ (with at least $7 \mathrm{~m}$ of both length and width),

- table tennis area of size $168 \mathrm{~m}^{2}$ (with at least $7 \mathrm{~m}$ of both length and width),

- fitness area of size $96 \mathrm{~m}^{2}$ or

- pool of size $6.67 \mathrm{~m} \times 16.67 \mathrm{~m}$ (for groups of 10 pupils). 
Additionally, Slovenian regulations determine that the gym has to have seating area that should accommodate at least one third of all pupils in school.

\section{Wardrobes}

Serbian regulations, in addition to central wardrobe, also allows the existence of special wardrobes in hallways in front of classrooms (while in practice those are usually coat racks within the classrooms). On the other hand, Slovenian regulations foresee only the central wardrobe placed at the school entrance, with the entry possible without going to the wardrobe. Wardrobes for grades 1-3 are functionally separate from the wardrobes for the older pupils and consist of open recessed wardrobe of width $0.2 \mathrm{~m}$ per pupil. Wardrobes for higher grades (4-6 and 7-9) consist of lockers, $0.32 \mathrm{~m}^{2}$ per pupil in size, with an individual key for pupils and a central key for school staff. Lockers are raised $0.15 \mathrm{~m}$ from floor to allow wet cleaning, while the upper part of lockers is inclined so that it does not collect paper and waste.

The existence of central wardrobe at the school entrance with individual lockers (for higher grades) provides greater comfort to pupils, as it simplifies their movement after entering the school and provides a sense of security for their belongings. Potential misuse of lockers is prevented by the existence of the central key for school staff.

\section{Sanitary facilities}

Although Slovenian regulations require a smaller number of sanitary facilities with respect to Serbian regulations, they nevertheless provide for significantly better sanitary equipment:

- sensor activated fixtures with limited hot water flow rate,

- liquid soap container above each sink,

- automatic hand dryers, in addition to paper towels,

- sensor activated lighting,

- wall-hung toilets,

- automatic flushing,

- $\quad$ protective casing for toilet paper, and

- closed garbage cans opened by foot.

In addition, toilet cabin walls are erected $0.1 \mathrm{~m}$ for easy cleaning, while toilet cabin doors must open outward for security reasons.

Let us also mention here a provision from Serbian regulations, rarely applied in practice, which stipulates that at least one drinking water fountain should be installed on each floor in school hallways, with 2-5 such fountains in the school yard. 


\section{Building access and parking}

Unlike Serbian regulations, Slovenian regulations stipulate that access to school building is differentiated by use, so that the entrances to the school, schoolyard and play yard are separated with distinct obstacles from the parking and driving surfaces.

Slovenian regulations also provide for one parking place per class and 3-9 additional parking spaces, depending on the school size, as well as bicycle storage space. On the other hand, Serbian regulations do not stipulate parking spaces, so that it is a common and consequence in Serbian schools that employees park their cars exactly in the schoolyard.

\section{Conclusion}

After a comparative analysis of Slovenian and Serbian regulations for the primary school design, we can highlight the following differences as the most important ones: school opening hours, space devoted to grades 1-3, school library and gym size.

Provision of the Slovenian regulations that schools always work in the morning shift, in addition to being beneficial for parents' time management, enables schools to offer its facilities in spare time to local community for adult education, lectures and conferences, for sporting events and concerts in the gym. On the other hand, schools in Serbia work in two shifts so that they can only rent their gyms for recreational purposes in the evenings after school hours.

Slovenian regulations pay special attention to space devoted to pupils in grades 1-3 (6-8 years), whose design represents a transition between kindergarten and school. Project design that combines indoor and outdoor teaching space with rest and play areas, aims to bring the concept of school to this age, without abrupt transition to sequence of classes in which the greatest children's joy is a long recess between classes, with the ultimate result of raising children education to a higher level. Further, significantly higher pupil density in classrooms in Serbia have twofold consequences: on one hand, it leads to excess levels of stimulation, stress and arousal, reductions in desired privacy levels and loss of control (Wohlwill \& van Vliet, 1985), while on the other hand, higher $\mathrm{CO}_{2}$ levels have larger influence on health, comfort and performance degradation of pupils in Serbia.

School library with computer classrooms is conceived in a more contemporary way in Slovenian regulations. It is also more spacious compared to that provided by Serbian regulations, allowing pupils easier and closer contact with books and the Internet. Exhibition area, which lies within the library according to Slovenian regulations, in Serbian schools can be found only on the walls of multipurpose rooms, which not only limits it to 
two-dimensional work, but does not allow teachers to lead their class to the exhibition tour without interrupting work of other teachers.

The gym provided by Slovenian regulations is larger and more appropriate, as it allows physical education classes to be held completely indoors, regardless of weather conditions. Additional auditorium space enables to use the gym not only for school events, but also to rent it for sport events and concerts.

Current regulations for the design of primary schools in Slovenia and Serbia have been compared here, in order to identify the main differences in the architecture of school space. To some extent, these architectural differences have long-term impact on the differences in the education of pupil in Slovenia and Serbia, as evident from the PISA test results. However, it is necessary to perform comparative analysis of other educational factors in Slovenia and Serbia as well, in order to obtain more detailed picture of educational systems and identify most appropriate directions of education reform that might bring Serbia closer to Slovenia and to the average of OECD countries.

\section{Acknowledgement}

The author is partially supported by the research grant ON174033 of the Ministry of Education and Science of Serbia.

\section{References:}

1. Anđelković, M. (1995). School buildings (in Serbian). Niš, Serbia: Faculty of Civil Engineering.

2. Armitage, M. (2005) The influence of school architecture and design on the outdoor play experience within the primary school, Paedagogica Historica $41 \quad$ (4-5), 535-553. https://doi.org/10.1080/00309230500165 734

3. Barrett, P., Zhang, Y., Moffat, J., \& Kobbacy, K. (2013) A holistic, multi-level analysis identifying the impact of classroom design on pupils' learning, Building and Environment 59, 678-689. https://doi.org/10.1016/j.buildenv.2012.09.016

4. Behnisch, G., \& Sabatke, M. (2003). Diversity and Democracy - 50 Years of School Design by Behnisch \& Partner, DETAIL (3), 148151.

5. Bloom, B.S. (1956). Taxonomy of educational objectives. New York, NY: Longmans, Green and Co.

6. Kadijević, Đ.M., Žakelj, A., \& Gutvajn, N. (2015) Explaining differences for Serbia and Slovenia in mathematics achievement in fourth grade, Nastava $i$ vaspitanje 64 (1), 21-38. Retrieved from https://doi.org/ 10.5937/NASVAS1501021K 
7. Kovačević, M. (2016) Statistical yearbook of the Republic of Serbia 2016. Belgrade, Serbia: Statistical office of the Republic of Serbia. Retrieved from http://www.stat.gov.rs/WebSite/repository/documents/00/02/28/ 89/05-OBRAZOVANJE.pdf

8. Lei, S.A. (2010) Classroom physical design influencing student learning and evaluations of college instructors: A review of literature, Education 131 (1), 128-134.

9. Marc, T.Č., \& Svetin, I. (2016) Statopis: Statistični pregled Slovenije 2016. Ljubljana, Slovenia: Statistični urad Republike Slovenije. Retrieved from http://www.stat.si/StatWeb/File/DocSysFile/9199

10. Niemeyer, D. (2003) Hard facts on smart classroom design. Lanham, MD: Scarecrow.

11. Ordinance on Standards of School Space, Equipment and Teaching Aids for Primary Schools (1990). Belgrade, Serbia: Official gazette of the Republic of Serbia - Educational gazette, 4.

12. OECD (2004). Learning for tomorrow's world: First results from PISA 2003, Paris, France: OECD Publishing, Retrieved from https://doi.org/10.1787/9789264006416-en

13. OECD (2007). PISA 2006, volume 2: Data, Paris, France: OECD Publishing, Retrieved from https://doi.org/10.1787/9789264040151en

14. OECD (2010). PISA 2009 results: What students know and can doStudent performance in reading, mathematics and science (Vol. I), Paris, France: OECD Publishing, Retrieved from https://doi.org/10.1787/ 9789264091450-en

15. OECD (2014). PISA 2012 results in focus: What 15-year-olds know and what they can do with what they know, Paris, France: OECD Publishing, Retrieved from http://www.oecd.org/pisa/keyfindings/pisa-2012-results-overview.pdf

16. Perkins, B., (2001). Building type basics for elementary and secondary schools, New York, NY: John Wiley \& Sons.

17. Plestenjak, M., Urbanc, J., Kovač, M., Leskovec, B., \& Strel, J. (1999) Instructions for the Construction of Primary Schools in the Republic of Slovenia - Part 1. Ljubljana, Slovenia: Ministry of education and sport of the Republic of Slovenia.

18. Popović, M., Cvetković, D., \& Krašna, M. (2015) Comparison of ICT in education between Slovenia and Serbia. In: Biljanović, P., Butković, Ž., Skala, K., Mikač, B., Cicin-Sain, M., Sruk, V., ..., Sokolić, A. (2015) Proceedings from MIPRO 2015: The $38^{\text {th }}$ International convention on information and communication technology, electronics and microelectronics. Opatija, Croatia: IEEE, 
pp. 721-725. https://doi.org/10.1109/MIPRO.2015.7160366

19. Rivlin, L.G., \& Wolf, M. (1972) The early history of a psychiatric hospital for children: expectations and reality, Environment and Behavior 4 (1), 33-72.

20. Safer, A.M., Farmer, L.S.J., Segalla, A., \& Elhoubi, A.F. (2005) Does the distance from the teacher influence student evaluations? Educational Research Quarterly 28 (3), 28-35. Retrieved from http://files.eric.ed.gov/fulltext/EJ718124.pdf

21. Tanner, C.K. (2000) The influence of school architecture on academic achievement, Journal of Educational Administration 38 (4), 309-330. https://doi.org/10.1108/09578230010373598

22. Wiegelmann, A. (2003). Education and Construction - a Typology of School-Building, DETAIL (3), 166-173.

23. Wohlwill, J.F., \& van Vliet, W. (1985) Habitats for children: The impacts of density, Hillsdale, NJ: Lawrence Erlbaum Associates. 